\title{
Modeling and Simulation of PV Engineering Mathematical Model Parameters Calculation Based on Newton-Raphson Method
}

\author{
Peng Zhang \\ School of Physics and Electrical Engineering, Weinan Normal University, \\ Weinan 714099, Shaanxi ,China \\ zuoye7983@126.com
}

\begin{abstract}
Traditional Photovoltaic (PV) mathematical models have advantage of high accuracy, but its characteristics are multi-parameters and non-linear, which makes it difficult to be solved. Obviously, these are not suitable for engineering design since it requires both complexity and accuracy. In this paper, a simplified precision engineering $P V$ mathematical model is proposed based on analysis of double diode PV cells mathematical model, and also gives a parameter calculation method based on NewtonRaphson method. Four different kinds of PV materials and variable resistance parameter characteristics are separately tested under different irradiance and temperature conditions. The results show that the proposed model can quickly and accurately reflect the PV model I-V and P-V characteristics, which has good versatility and sensitivity, and provides strong support for $P V$ system related research.
\end{abstract}

Keywords: PV modules; Mathematical model; Engineering mathematical model; Output characteristic

\section{Introduction}

Currently, increasing exhausted traditional fossil energy structure has caused a lot of greenhouse gas emissions and serious environmental pollution. It is inevitable to develop a new and clean renewable energy in the scientific community. Undoubtedly, solar energy has advantages of non-polluting, distributes widely and facilitates acquisition, so solar energy is an ideal alternative energy for traditional energy [1-3]. What's more, PV power generation is a significant approach to make use of the large-scale solar energy available.

PV electrical characteristic is a vital foundation of basic research on PV grid, MPPT and inverter control design, but PV power has strongly nonlinear characteristic, and its output characteristics of $\mathrm{I}-\mathrm{V}$ and $\mathrm{P}-\mathrm{V}$ are easily affected by radiation intensity and environment temperature. At present, PV model mainly includes mathematical model and engineering model. Mathematical model mainly includes double diode equivalent circuit model and two diode equivalent circuit model, these models can get high accuracy, but because of its non-linear, multi-parameter characteristics, and involves transcendental equation, so it is difficult to be solved, and not suitable for engineering model needs. In order to meet precision and efficiency requirements, researchers have proposed a variety of modeling methods of PV engineering models, a PV engineering mathematical model is proposed which is easily calculated, it combines with similarity between PV curve and the particle projectile motion trajectory [4]. Y. Y. Sun proposed four parameters simplified silicon solar cells engineering model [5], an engineering mathematical model which based on compensation parameter fitting correction method is proposed [6], L. L. Peng [7] established a common PV module engineering simulation model in MATLAB. 
PV engineering mathematical model is a set of nonlinear equations, in the model of parameter extraction, it has drawback that the extract of key parameters is of low accuracy, the initial value is difficult to be determined, and the calculate convergence is slow. In order to reduce the difficulty of equation solving, some methods [8-9] use typical value method, but these models have poor applicability; a numerical method [10] is proposed which can calculate 3 parameters of single exponential model at the same time, but large number of derivative operation reduces the operating efficiency; some methods [11-12] introduce intelligent algorithms, such as Particle Swarm Optimization (PSO) and BP neural network algorithms to get parameters, but it requires a lot of experimental data, which limits its application.

This paper analyzes the double diode equivalent circuit model, establishes an accurate engineering mathematical model through reservations series resistance on the basis of precise mathematical model. Newton - Raphson parameter calculation method is designed to solve PV module model, it has advantage of fast convergence, if we have good initial values, it can accelerate convergence, and precise solution can be got after generally 4-5 times iteration, at the same time meets the requirement of speed and accuracy. By means of the proposed method, this paper sets up a simulation model for typical Solar MSX60 PV modules in MATLAB. The established PV module model is tested for different materials and series resistance parameters, the model output characteristics for different irradiance and temperature are also tested, results show that the model has sufficient sensitivity, which can accurately reflect the characteristics of PV module in different conditions.

\section{Analysis of mathematical model and engineering mathematical model}

\subsection{Double diode PV Cell Mathematical Model}

Double diode equivalent circuit model considers the reverse avalanche breakdown effect, which has a higher engineering accuracy. If we use $U$ and $J$ respectively express PV cell terminal voltage and load current density, use quantum mechanics and semiconductor materials properties derivation, $\mathrm{PV}$ cell current density $\mathrm{J}$ can be expressed as:

$$
J=J_{p h}-J_{i}=J_{p h}-J_{0}\left(\exp \left[\frac{q U}{k T}\right]-1\right)
$$

Binding assay measured the terminal characteristics of PV cells, in order to achieve the engineering required accuracy, need to add series resistance $\left(R_{s}\right)$ and shunt resistance $\left(R_{s h}\right), \mathrm{PV}$ cells double diode equivalent circuit model as Figure 1.

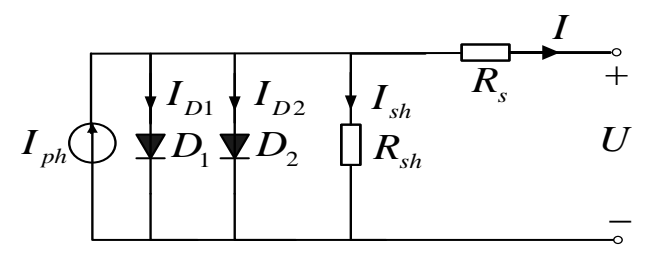

Figure 1. PV Cell Double Diode Equivalent Circuit

According to KCL law PV output current is:

$$
I=I_{p h}-I_{D 1}-I_{D 2}-I_{s h}
$$

Where, 


$$
\begin{gathered}
I_{p h}=I_{s c}\left(\frac{S}{1000}+K_{0}\left(T-T_{r e f}\right)\right) \\
K_{0}=\frac{I_{S C(T 2)}-I_{S C(T 1)}}{T_{2}-T_{1}} \\
I_{D 1}=I_{s 1}\left(e^{\frac{q\left(V+I R_{s}\right)}{a_{1} k T}}-1\right) \\
I_{D 2}=I_{s 2}\left(e^{\frac{q\left(V+I R_{s}\right)}{a_{2} k T}}-1\right) \\
I_{s i}=I_{d o}\left(\frac{T}{T_{r e f}}\right)^{3}\left(\exp \left[\frac{q E_{g}}{a_{i} k}\left(\frac{1}{T_{r e f}}-\frac{1}{T}\right)\right]\right) \\
I_{s h}=\frac{V+I R_{s}}{R_{s h}}
\end{gathered}
$$

Equation (2) to (8) is double diode PV cell mathematical model expression. Where, I is PV cell output current; $\mathrm{U}$ is PV cell output voltage; $\mathrm{I}_{\mathrm{sc}}$ is the short-circuit current; $\mathrm{S}$ is solar insolation, $\mathrm{T}$ is the surface temperature of PV cell, $\mathrm{I}_{\mathrm{s} 1}$ and $\alpha_{1}$ are diode $\mathrm{D}_{1}$ reverse saturation current and quality factor; $\mathrm{Is}_{2}$ and $\alpha_{2}$ are diode $\mathrm{D}_{2}$ reverse saturation current and quality factor; $\mathrm{q}$ is the electron charge, $1.602 \times 10^{-19} \mathrm{C}$; $\mathrm{K}$ is Boltzmann's constant, $1.38 \times 10^{-23} \mathrm{~J} / \mathrm{K}, \mathrm{E}_{\mathrm{g}}$ is band-gap energy constant.

PV module can be structured by series and parallel PV cells to meet the requirements of large-scale power generation [13]. It is generally considered that cells in PV module have same characteristic parameters, if we neglect the connection resistance of PV cells and assuming that they have ideal consistency, thus PV module equivalent circuit can be shown as Figure 2.

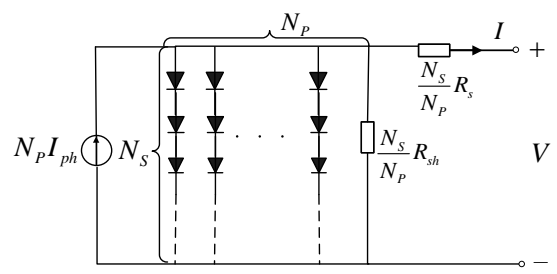

\section{Figure 2. PV Module Equivalent Circuit}

Relationship of PV module output voltage and current as equation (9):

$$
I=N_{P} I_{p h}-N_{P} I_{s 1}\left(e^{\frac{q\left(V / N_{S}+I R_{s} / N_{P}\right)}{a_{1} k T}}-1\right)-N_{P} I_{s 2}\left(e^{\frac{q\left(V / N_{S}+I R_{s} / N_{P}\right)}{a_{2} k T}}-1\right)-N_{P} \frac{V / N_{S}+I R_{s} / N_{P}}{R_{s h}}
$$

Where, $\mathrm{N}_{\mathrm{S}}$ and $\mathrm{N}_{\mathrm{P}}$ are the number of PV cells in series and in parallel.

\subsection{Engineering Mathematical Model}

PV cell double diode equivalent circuit mathematical model has sufficient accuracy, but it's more complex to solve, and it's difficult to meet engineering needs [14-15]. Since PV cell is not sensitive to shunt resistance $R_{\text {sh }}$, it can be assumed to be infinity without causing earth leakage current, it can be ignored in the engineering mathematical models. Small changes of $\mathrm{R}_{\mathrm{s}}$ can significantly affect the output characteristics of PV cell, in engineering mathematical model it must be retained. Therefore, PV cell engineering mathematical model expression can be obtained as following: 


$$
\begin{gathered}
I=I_{p h}-I_{d 0}\left(\mathrm{e}^{\frac{q\left(V+I R_{s}\right)}{a k T}}-1\right) \\
I_{p h}=\frac{S I_{s c\left(T_{1}\right)}}{S_{r e f}}\left(1+K_{0}\left(T-T_{1}\right)\right) \\
K_{0}=\frac{I_{s c(T 2)}-I_{s c(T 1)}}{T_{2}-T_{1}} \\
I_{d 0}=I_{d 0\left(T_{1}\right)}\left(\frac{T}{T_{1}}\right)^{\frac{3}{n}} e^{\frac{-q E_{g}}{a k\left(1 / T_{1}-1 / T\right)}} \\
I_{d 0(T 1)}=\frac{I_{s c\left(T_{1}\right)}}{e^{\frac{q V_{o c\left(T_{1}\right)}}{a k T_{1}}}-1} \\
R_{s}=-\frac{d V}{d I_{V_{o c}}}-\frac{\alpha k T_{1} e^{\frac{q V_{o c\left(T_{1}\right)}}{\alpha k T_{1}}}}{I_{d 0\left(T_{1}\right)} q}
\end{gathered}
$$

Where, equation (10) is PV cell output current, in equation (11) the relationship between photocurrent and temperature is linear, equation (12) is derived photocurrent relationship with temperature changes. When the PV cells in a completely blackout, the output voltage and current relationship is given by Shockley equation. Equation (13) (14) reflect open circuit voltage and short circuit current calculation diode reverse saturation current and temperature relation. Equation (15) is solving for series resistance.

\section{Newton- Raphson Parameter for the Solution of PV Model}

PV manufacturers usually provide standard environment test parameters for users, and they adopt these parameters to identify other unknown variables. According to the actual needs, PV modules can be connected to certain topology by users, PV module is generally equivalent to a cell in practice; PV module can be described by equation (10) (15). PV mathematical model has five unknown constants, sample data onto current and voltage can be obtained by sampling PV module, fitted by least squares method, such as equation (16).

$$
X^{2}(x)=\sum_{i=1}^{N}\left[\frac{I_{i}\left(V_{i}\right)-I\left(V_{i}, x\right)}{\sigma_{i}}\right]^{2}
$$

Where, $\mathrm{N}$ is sample collection number of current and voltage, $\mathrm{X}$ is a vector which constituted by solving variables $\left(\mathrm{R}_{\mathrm{s}}, \mathrm{R}_{\mathrm{sh}}, \alpha, \mathrm{I}_{\mathrm{do}}, \mathrm{I}_{\mathrm{sc}}\right), \mathrm{I}_{\mathrm{i}}\left(\mathrm{V}_{\mathrm{i}}\right)$ is the actual measured $\mathrm{PV}$ module output current value when voltage is equal to $\mathrm{V}_{\mathrm{i}}, \mathrm{I}_{\mathrm{i}}\left(\mathrm{V}_{\mathrm{i}}, \mathrm{x}\right)$ is calculated output current value when voltage is equal to $\mathrm{V}_{\mathrm{i}}, \sigma_{i}$ is The standard deviation.

According to undetermined coefficient method, we can determine other unknown variables $\left(\mathrm{I}_{\mathrm{ph}}, \mathrm{I}_{0}, \mathrm{R}_{\mathrm{s}}, \mathrm{R}_{\mathrm{sh}}\right)$, then using the Newton - Raphson method for solving nonlinear equations. Firstly, I-V curve through three special points as short circuit point, open circuit point and MPP (maximum power point), so we can get three equations as (17): 


$$
\left\{\begin{array}{l}
0=I_{p h}-I_{0}\left[\exp \left(\frac{q V_{o c}}{\alpha k T}\right)-1\right]-\frac{V_{o c}}{R_{s h}} \\
I_{s c}=I_{p h}-I_{0}\left[\exp \left(\frac{q R_{s} I_{s c}}{\alpha k T}\right)-1\right]-\frac{R_{s} I_{s c}}{R_{s h}} \\
I_{m}=I_{p h}-I_{0}\left[\exp \left(\frac{q\left(V_{m}+R_{s} I_{\mathrm{m}}\right.}{\alpha k T}\right)-1\right]-\frac{R_{s} I_{m}+V_{m}}{R_{s h}}
\end{array}\right.
$$

Maximum power optimization model can be obtained by equation (18):

$$
\left\{\begin{array}{l}
\max \quad P=V\left[I_{p h}-I_{0}\left[\exp \left(\frac{q\left(V+R_{s} I\right)}{\alpha k T}\right)-1\right]-\frac{R_{s} I+V}{R_{s h}}\right] \\
\text { s.t. } I=I_{p h}-I_{0}\left[\exp \left(\frac{q\left(V+R_{s} I\right)}{\alpha k T}\right)-1\right]-\frac{R_{s} I+V}{R_{s h}}
\end{array}\right.
$$

The maximum power point $\left(V_{\mathrm{m}}, I_{m}\right)$ meets Kuhn-Tucker (KT) optimization conditions as:

$$
\begin{gathered}
\left\{\begin{array}{l}
\left.\frac{\partial H}{\partial V}\right|_{m}=0 \\
\left.\frac{\partial H}{\partial I}\right|_{m}=0
\end{array}\right. \\
H=V\left[I_{p h}-I_{0}\left[\exp \left(\frac{q\left(V+R_{s} I\right)}{\alpha k T}\right)-1\right]-\frac{R_{s} I+V}{R_{s h}}\right] \\
+\lambda\left[I-I_{p h}+I_{0}\left[\exp \left(\frac{q\left(V+R_{s} I\right)}{\alpha k T}\right)-1\right]-\frac{R_{s} I+V}{R_{s h}}\right]
\end{gathered}
$$

Simultaneous equations (17) (20) can obtain 5 nonlinear equations (21), the unknown variable is also 5, PV model characteristics can be obtained by solve these equations.

$$
\left\{\begin{array}{l}
0=I_{p h}-I_{0}\left[\exp \left(\frac{V_{o c}}{V_{t}}\right)-1\right]-\frac{V_{o c}}{R_{s h}} \\
I_{s c}=I_{p h}-I_{0}\left[\exp \left(\frac{R_{s} I_{s c}}{V_{t}}\right)-1\right]-\frac{R_{s} I_{s c}}{R_{s h}} \\
I_{m}=I_{p h}-I_{0}\left[\exp \left(\frac{V_{m}+R_{s} \mathrm{I}_{\mathrm{m}}}{V_{t}}\right)-1\right]-\frac{R_{s} I_{m}+V_{m}}{R_{s h}} \\
0=I_{m}+\lambda\left\{\frac{I_{0}}{V_{t}}\left[\exp \left(\frac{V_{m}+R_{s} \mathrm{I}_{\mathrm{m}}}{V_{t}}\right)+\frac{1}{R_{s h}}\right\}\right. \\
0=V_{m}\left\{-\frac{I_{0} R_{s}}{V_{t}}\left[\exp \left(\frac{V_{m}+R_{s} \mathrm{I}_{\mathrm{m}}}{V_{t}}\right)-\frac{R_{s}}{R_{s h}}\right\}+\lambda\left\{1+\frac{I_{0} R_{s}}{V_{t}}\left[\exp \left(\frac{V_{m}+R_{s} \mathrm{I}_{\mathrm{m}}}{V_{t}}\right)+\frac{R_{s}}{R_{s h}}\right\}\right.\right.
\end{array}\right.
$$

It is difficult to directly solve nonlinear equations; Figure 3 is flow chart using Newton - Raphson algorithm solves process. 


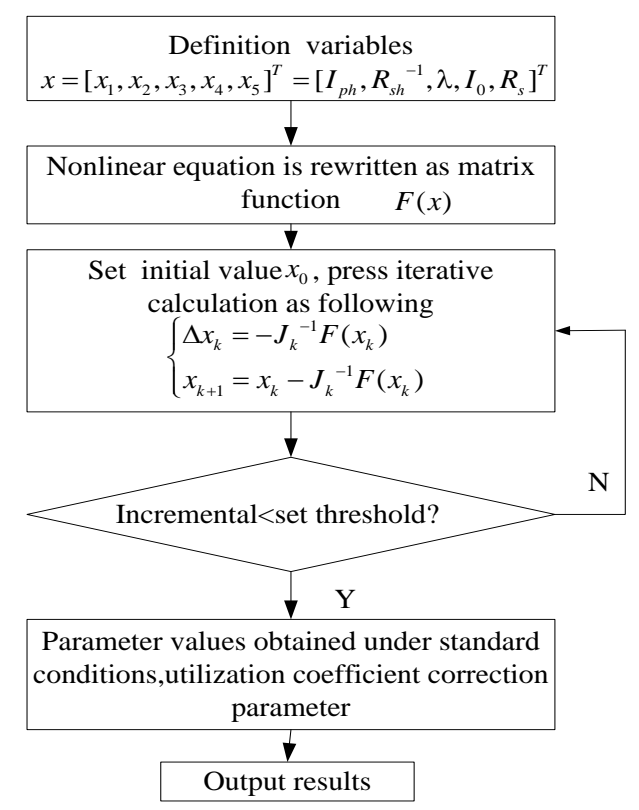

Figure 3. Flow Chart of Newton - Raphson Algorithm

Where, the nonlinear equations $\mathrm{F}(\mathrm{x})$ are equation (22):

$$
F(x)=\left\{\begin{array}{l}
x_{1}-x_{4}\left[\exp \left(\frac{V_{o c}}{V_{t}}\right)-1\right]-x_{2} V_{o c} \\
1-x_{4}\left[\exp \left(\frac{x_{5} I_{s c}}{V_{t}}\right)-1\right]-x_{2} x_{5} I_{s c}-I_{s c} \\
x_{1}-x_{4}\left[\exp \left(\frac{V_{m}+x_{5} I_{m}}{V_{t}}\right)-1\right]-x_{2} x\left(V_{m}+x_{5} I_{m}\right)-I_{m} \\
I_{m}+x_{3}\left[\frac{x_{4}}{V_{t}} \exp \left(\frac{V_{m}+x_{5} I_{m}}{V_{t}}\right)+x_{2}\right] \\
\left(x_{3}-V_{m}\right)\left[\frac{x_{4} x_{5}}{V_{t}} \exp \left(\frac{V_{m}+x_{5} I_{m}}{V_{t}}\right)+x_{2} x_{5}\right]+x_{3}
\end{array}\right.
$$

Where $\mathrm{J}_{\mathrm{k}}$ is Jacobian Matrix of $\mathrm{F}$ at the point $\mathrm{x}_{\mathrm{k}}$, the coefficient correction is equation (23):

$$
\left\{\begin{array}{l}
I_{0}=I_{o_{-} n}\left(\frac{T}{T_{r e f}}\right)^{3} \exp \left[\frac{q E_{g}}{\alpha k}\left(\frac{1}{T_{r e f}}-\frac{1}{T}\right)\right] \\
I_{p h}=\frac{S I_{p h_{-} n}}{S_{r e f}\left(1+K_{i} \Delta T\right)} \\
V_{o c}=V_{o c_{-} n}\left(1-K_{v} \Delta T\right) \ln \left[e+0.5\left(\frac{S}{S_{r e f}}-1\right)\right]
\end{array}\right.
$$




\subsection{Analysis of PV Array Output Characteristics}

Choose typical Solarex MSX60 PV module for modeling, the module consists of 36 cells. Test parameters is provided to user according to the manufacturer (in standard test environment where temperature $\mathrm{t}=25^{\circ} \mathrm{C}$, the radiation intensity $\mathrm{S}=1000 \mathrm{~W} / \mathrm{m}^{2}$ measured data), specific parameters [16-17] are shown in Table 1.

\section{Table 1. Solarex MSX60 PV Module Main Parameters $\left(t=25^{\circ} \mathrm{C}, \mathrm{S}\right.$ $=1000 \mathrm{~W} / \mathrm{m} 2$ )}

\begin{tabular}{cc}
\hline Parameter & Value/Unit \\
\hline Maximum power $/ \mathrm{P}_{\mathrm{m}}$ & $60 / \mathrm{W}$ \\
Peak voltage $/ \mathrm{V}_{\mathrm{m}}$ & $17.1 / \mathrm{V}$ \\
Open circuit voltage $/ \mathrm{V}_{\mathrm{OC}}$ & $21.1 / \mathrm{V}$ \\
Peak current $/ \mathrm{I}_{\mathrm{m}}$ & $3.5 / \mathrm{A}$ \\
Short circuit current $/ \mathrm{I}_{\mathrm{SC}}$ & $3.8 / \mathrm{A}$ \\
Open circuit voltage temperature coefficient & $-73 / \mathrm{mV}^{\circ} \mathrm{C}^{-1}$ \\
Short circuit current temperature coefficient & $3 / \mathrm{mA}^{\circ} \mathrm{C}^{1}$ \\
Power temperature coefficient & $-0.38 / \mathrm{W}^{\circ} \mathrm{C}^{-1}$ \\
\hline
\end{tabular}

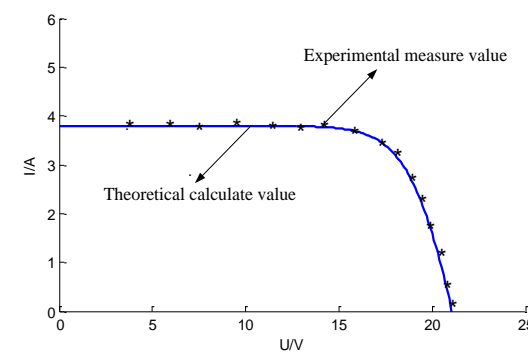

(a) I-U curve of PV array

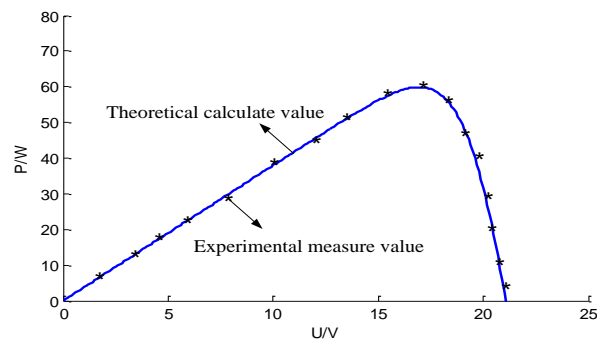

(b) P-U curve of PV array

Figure 4. Theoretical Values Compared with Actual Measured Values

According to above mathematical model to obtain I-U and P-U output characteristics of PV array under standard test environment, compare experimental curve with measurement curve, as shown in Figure.4. Figure 4 (a) is I-U output characteristic theoretical calculate value and experimental measure value, Figure 4 (b) is P-U output characteristic theoretical calculate value and experimental measure value. Figure 4 shows that theoretical value and actual measured values are in good agreement. We can see that there is error in the simulation result, the reason is that to simplify the problem, we assume PV cells have the same characteristic parameters, ignores diode losses and connection resistance, but error is within engineering accuracy permission range.

\section{Sensitivity Test of PV Model Component}

\subsection{Analysis of Different Materials Effect}

When sunlight strikes solar cell surface, photons through antireflection film, and then irradiated to the semiconductor surface, conduction band electron absorb photons energy transitions become free electrons, connect positive and negative of PV cells using a wire, current can flow through load. Different semiconductor materials exhibit different characteristics, the first generation PV cells mainly include single-crystal silicon solar 
cell, polycrystalline silicon solar cell and amorphous silicon solar cell, non-silicon thin film battery material belongs to the second generation PV cells, in practice, the silicon PV cell still occupies an important position. Table 2 is four typical kinds of solar cell material parameters.

Table 2. Main Parameters of Different Materials

\begin{tabular}{ccc}
\hline Material & Diode quality factor & Bandgap / eV \\
\hline Si-mono & 1.2 & 1.12 \\
AsGa & 1.3 & 1.42 \\
CdTe & 1.5 & 1.45 \\
a-si:H & 1.8 & 1.75 \\
\hline
\end{tabular}

In accordance to Table 1 parameters, under standard conditions (temperature $\mathrm{t}=25^{\circ} \mathrm{C}$, radiation intensity $S=1000 \mathrm{~W} / \mathrm{m}^{2}$ ), input parameters to the engineering mathematical model, test the commonality performance of the engineering mathematical model. Figure 5 is I-V output characteristics of different materials, we can see that the diode quality factor $\alpha$ has greater impact on the output current, and $\alpha$ more greater the output current more smaller; however bandgap at standard temperature conditions has poor influence on the output current. Figure 6 is P-V output characteristics of different materials, it can be seen that under the same ambient conditions, MPP of the various materials are present in the output voltage of $17 \mathrm{~V} \sim 18 \mathrm{~V}$ range. It can be seen that due to the different materials of diode quality factor $\alpha$ and bandgap parameter, I-V and P-V output characteristics of engineering mathematical model can better reflect the differences in various materials, with good commonality performance.

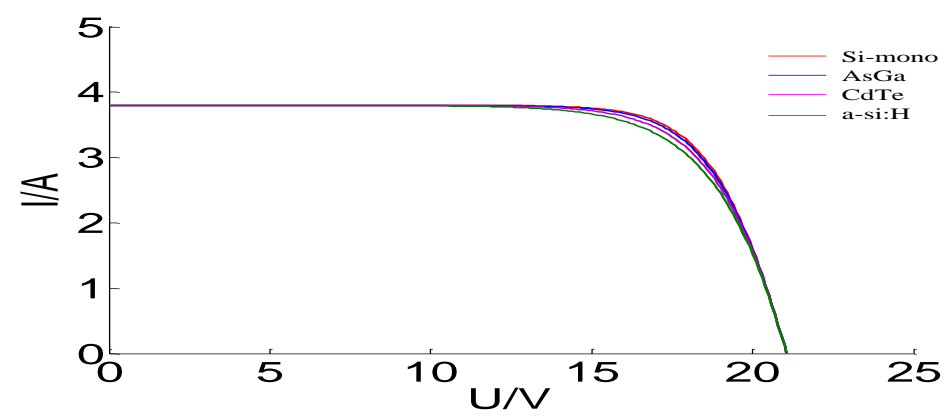

Figure 5. I-V Output Characteristics of Different Materials

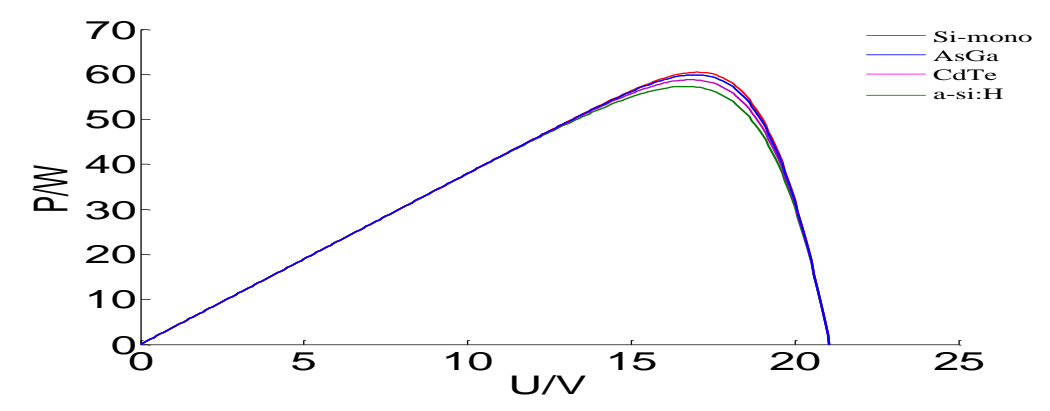

Figure 6. P-V Output Characteristics of Different Materials 


\subsection{Analysis of Series Resistance Parameters Effect}

In engineering mathematics model retains series resistance $R_{s}$, because its change can significantly affect the output characteristics of PV cells. Under standard environment, taking single-crystal silicon (Si-mono) material, test series resistance parameters characteristics affecting of proposed engineering mathematical model, to verify sensitivity of the model.

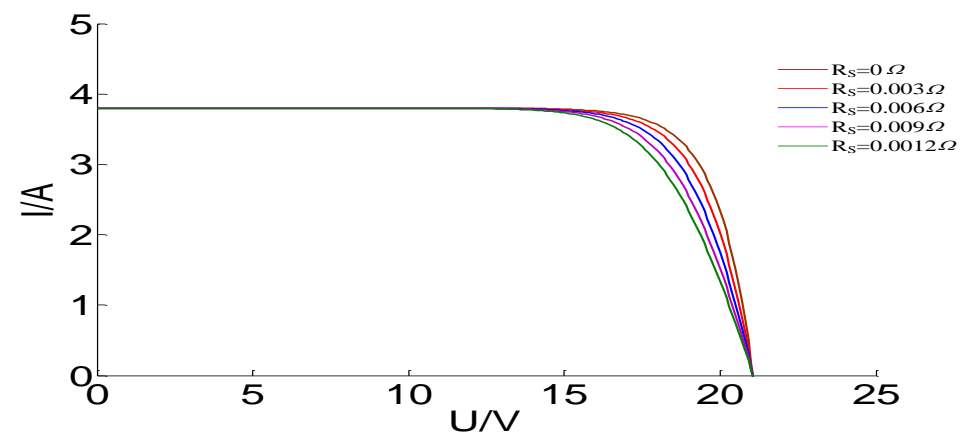

Figure 7. Influence of $R_{s}$ on I-V Output Characteristics

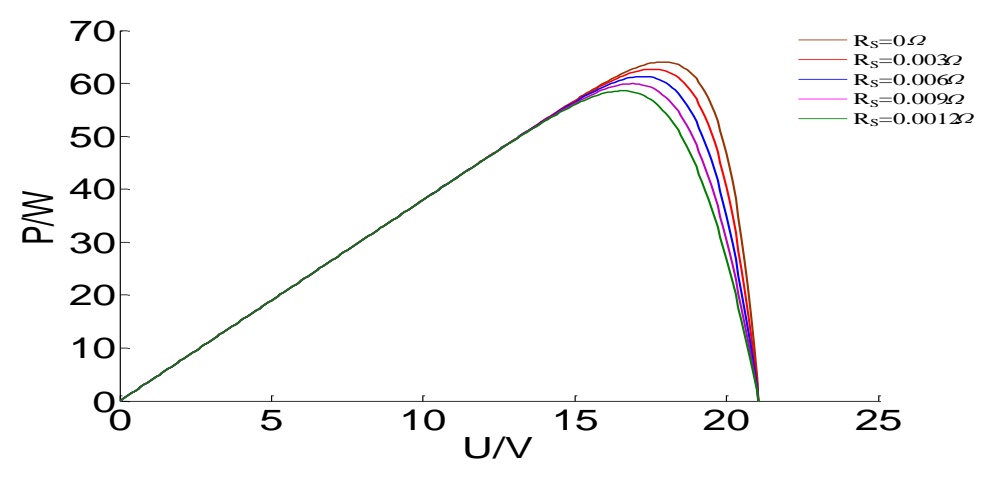

Figure 8. Influence of $\mathbf{R}_{\mathrm{s}}$ on P-V Output Characteristics

PV modules can be constituted by serial and parallel PV cells, it is generally considered that PV cells in series and parallel have same characteristic parameters, so we can neglect the connection resistance of PV cells and assuming what they have desired consistency. Figure 7 and Figure 8 are respectively series resistance $R_{s}$ influence of I-V output and P-V output characteristics within the range $0 \Omega \sim 0.0012 \Omega$. It can be seen in Figure 7, series resistance is inversely proportional to the output current, different parameters can be obtained by adjusting the number of parallel PV array string. In Figure 8, series resistance has significant impact on MPP amplitude; corresponding MPP voltage variation is small.

\section{Analysis of PV Engineering Mathematics Model Output Characteristic}

In order to validate proposed engineering mathematical model and effectiveness of algorithm for solving, take typical Solar MSX60 type PV cell components for example, build simulation model in MATLAB. 


\subsection{PV Module Output Characteristics under Different Irradiation Intensity}

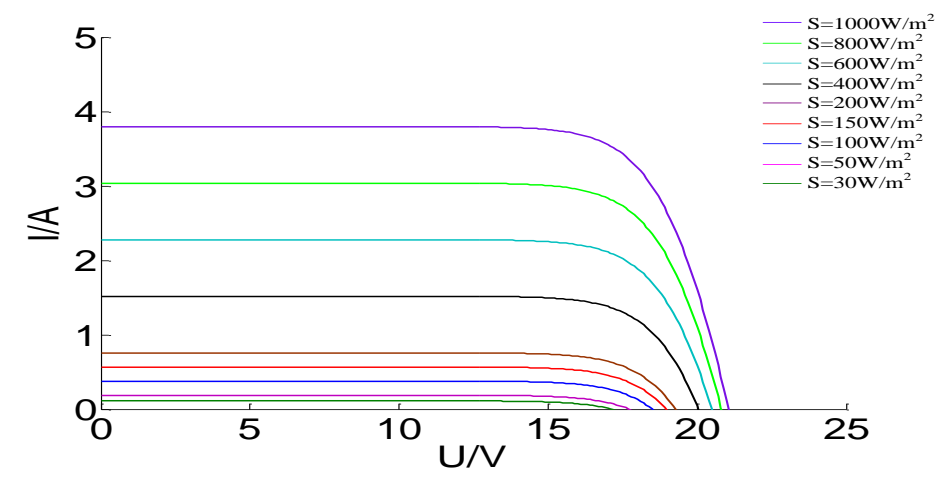

Figure 9. I-V Curves at Different Radiation Intensity $\left(t=25^{\circ} \mathrm{C}\right)$

During the operation of PV modules, the irradiation intensity changes vulnerable to surrounding environment, such as shadows clouds, buildings, etc. which caused global shading, but the temperature does not change instantaneously. In order to simulate this condition, set temperature $\mathrm{t}=25^{\circ} \mathrm{C}$ to be constant, changed radiation intensity in range of $1000 \mathrm{~W} / \mathrm{m}^{2} \sim 30 \mathrm{~W} / \mathrm{m}^{2}$, examine the model output characteristic with radiation changes.

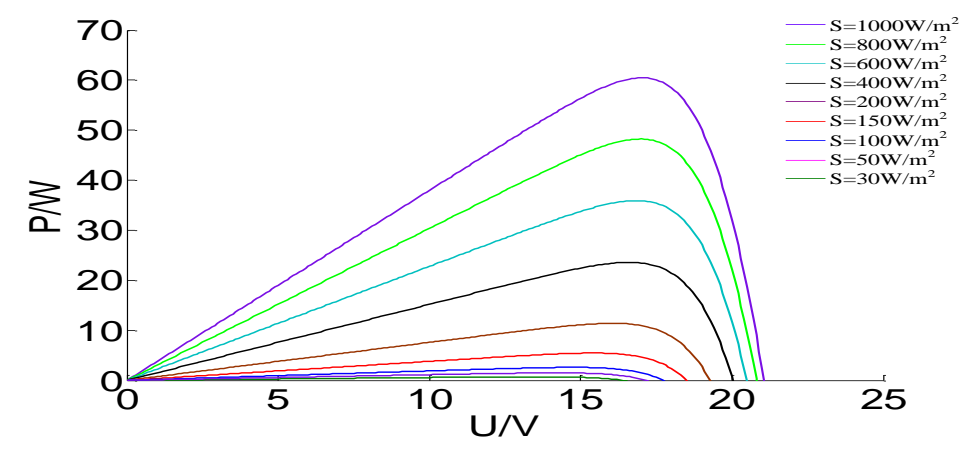

Figure 10. P-V Curves at Different Radiation Intensity $\left(t=25^{\circ} \mathrm{C}\right.$

Table 3. PV Module Characteristics at Different Radiation Intensity $\left(t=25^{\circ} \mathrm{Q}\right)$

\begin{tabular}{ccc}
\hline Radiation intensity / W/m ${ }^{2}$ & $\begin{array}{c}\text { Maximum power } \\
\text { /W }\end{array}$ & Voltage /V \\
\hline 1000 & 59.8908 & 16.9000 \\
800 & 47.6698 & 16.9000 \\
600 & 35.3626 & 16.9000 \\
400 & 22.9802 & 16.9000 \\
200 & 11.1268 & 15.7999 \\
150 & 8.1864 & 15.5000 \\
100 & 5.3010 & 15.0000 \\
50 & 2.5124 & 14.2999 \\
30 & 1.4448 & 13.7999 \\
\hline
\end{tabular}


Figure 9 and Figure 10 are respectively $\mathrm{I}-\mathrm{V}$ and $\mathrm{P}-\mathrm{V}$ curve at $\mathrm{t}=25^{\circ} \mathrm{C}$ under different illuminance, Table 3 is the characteristics of PV modules at different radiation intensities. It can be seen in Figure 9, when irradiation intensity decreases, short circuit current has significant change in the range $0 \mathrm{~A} \sim 4 \mathrm{~A}$, but little effect to open circuit voltage, corresponding in the range $17 \mathrm{~V} \sim 22 \mathrm{~V}$. In Figure 10 and Table 3, the change of radiation intensity in range of $1000 \mathrm{~W} / \mathrm{m}^{2} \sim 400 \mathrm{~W} / \mathrm{m}^{2}$, MPP at $59.8908 \mathrm{~W} \sim 22.9802 \mathrm{~W}$ range received radiation intensity influence is obvious, but the corresponding voltage in the vicinity of $16.9000 \mathrm{~V}$ change is not obvious; In the $400 \mathrm{~W} / \mathrm{m}^{2} \sim 30 \mathrm{~W} / \mathrm{m}^{2}$ of low-light conditions, MPP sharp dropped to $1.4448 \mathrm{~W}$, and corresponds voltage in range of $16.9000 \mathrm{~V} \sim 13.7999 \mathrm{~V}$ changes is relatively obvious.

\subsection{PV Module Output Characteristics at Different Temperatures}

The bandgap of PV modules material decreases at high temperature conditions, thus reducing open circuit voltage of PV cell, even format hot spots in local area which damages on PV module, it is also one of main factors that leading to decline of conversion efficiency of solar cells. Maintain irradiance $1000 \mathrm{~W} / \mathrm{m}^{2}$ constant while varying temperature changes in range of $0^{\circ} \mathrm{C} \sim 100^{\circ} \mathrm{C}$, test temperature characteristic variations of model output.

Figure 11 and Figure 12 are respectively I-V and P-V curves (radiation intensity $\mathrm{S}=1000 \mathrm{~W} / \mathrm{m}^{2}$ ) with different temperature, Table 4 is PV modules characteristics at different temperatures. It can be seen that in Figure 11 as temperature increases, open circuit voltage is gradually reduced from $23.5 \mathrm{~V}$ to $15.2 \mathrm{~V}$, temperature has greater impact on open circuit voltage, but short circuit current change is not obvious. In Figure 12 and Table 4, with rise of temperature in range of $0^{\circ} \mathrm{C} \sim 100^{\circ} \mathrm{C}$, MPP felled from $66.0778 \mathrm{~W}$ to $39.9495 \mathrm{~W}$, a drop of $39.5 \%$, showing that the temperature has a significant effect on MPP.

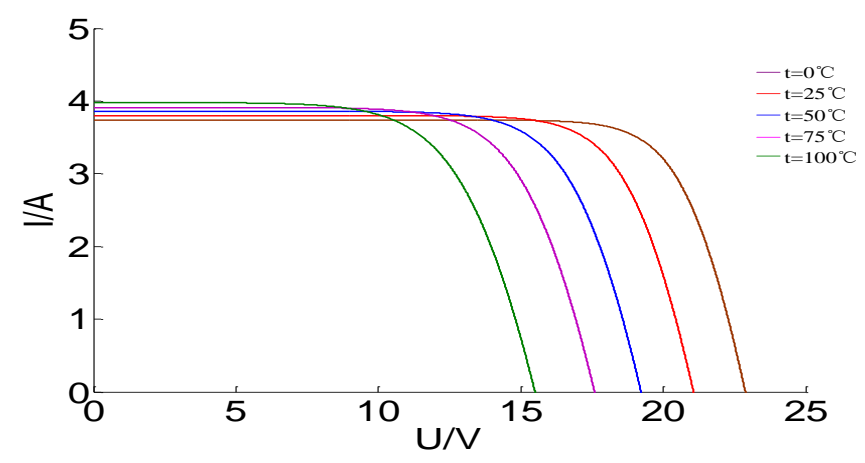

Figure 11. I-V Curves at Different Temperatures $\left(S=1000 \mathrm{~W} / \mathrm{m}^{2}\right)$

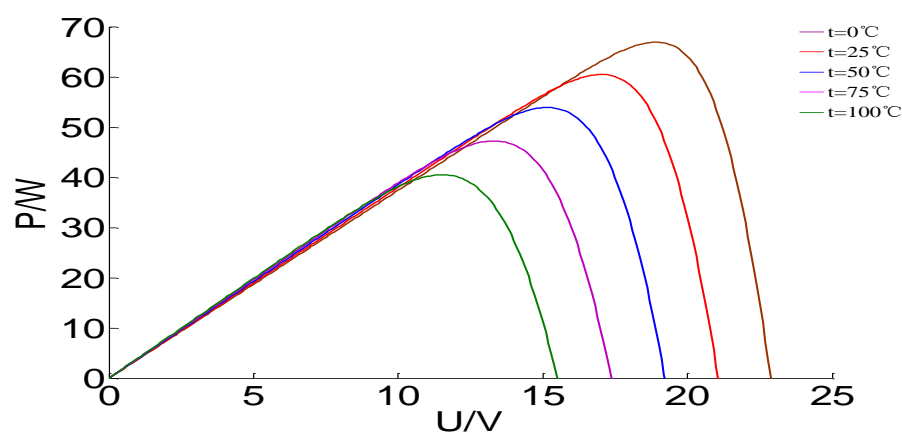

Figure 12. P-V Curves at Different Temperatures (S=1000W/m2) 
Table 4. PV Module Characteristics at Different Temperatures ( $\left.\mathrm{S}=1000 \mathrm{~W} / \mathrm{m}^{2}\right)$

\begin{tabular}{ccc}
\hline Cell Temperature $/{ }^{\circ} \mathrm{C}$ & $\begin{array}{c}\text { Maximum power } \\
/ \mathrm{W}\end{array}$ & Voltage $/ \mathrm{V}$ \\
\hline 100 & 39.9495 & 11.5000 \\
75 & 46.6498 & 13.2999 \\
50 & 53.3155 & 15.1000 \\
25 & 59.8908 & 16.9000 \\
0 & 66.0778 & 18.4000 \\
\hline
\end{tabular}

\section{Conclusion}

PV cells mathematical model have strongly nonlinear, multi-parameter that cannot meets needs of practical engineering problems, this paper proposed PV cells engineering mathematics model based on double diode. Use Newton-Raphson iterative method, which is a relatively simple method to compute the model parameters. Use this method created engineering mathematical model of PV module in MATLAB, test and analysis the PV components in different environmental temperature, irradiation intensity conditions. The results show that the proposed method has simple characteristics, for different PV materials exhibit good versatility, the model can accurately reflect the output characteristics of PV modules under different conditions, fit for modeling and simulation of large-scale PV power generation system.

\section{Acknowledgements}

This work is partially supported by Civilian Integration Foundation of Shaanxi Province (15JMR14). The authors also gratefully acknowledge the helpful comments and suggestions of the reviewers, which have improved the presentation.

\section{References}

[1] S. Mekhilef, R. Saidur, A. Safari, A Review on Solar Energy Use in Industries, Renew. Sustain. Energy Rev, vol.15, pp.1777-1790, (2011).

[2] M. G. Villalva, J. R. Gazoli, Comprehensive Approach to Modeling and Simulation of Photovoltaic Arrays, IEEE Trans. Power Electron. vol.24, pp.1198-1208, (2009).

[3] K. Nishioka; N. Sakitani; Y.Uraokal, Analysis of Muti-crystalline Silicon Solar Cells by Modified 3diode Equivalent Circuit Model Taking Leakage Current Through Periphery into Consideration, Solar Energy Mater Solar Cells, vol.91, pp.1222-1227, (2007).

[4] W. Fu, L. Zhou, K. Guo, Q. Liu, L. Dai, Y. Huang, Research on Engineering Analytical Model of Solar Cells, Transactions of China Electro technical Society, vol.26, no.10, pp.211-216, (2011).

[5] Y. Y. Sun, H. F. Xiao, S. J. Xie, Parameters Solution and Verification of Solar Cells' Simplified Model, Power Electronics. vol. 43, no.6 pp. 44-46, (2009).

[6] M. Q. Mao, S. J. Yu, J. H. Su. Versatile Matlab Simulation Model for Photovoltaic Array with MPPT Function, Journal of System Simulation, vol. 17, no.5 pp. 1248-1251, (2005).

[7] L. L. Peng, Y. Z. Sun, C. Meng, Y. J. Chen, Generalized Photovoltaic Array Module Using Matlab/ simulink, Journal of Donghua University, vol. 37, no.1 pp. 90-94, (2009).

[8] Q. Tian, Z. M. Zhao, X. Y. Han, Sensitivity Analysis and Parameter Extraction of Photovoltaic Cells Model, Electric Power Automation Equipment, vol. 33, no.5 pp. 119-124, (2013).

[9] X. Y. Kong, Y. M. Xu, Y. W. Zeng, S. Tao, X. N. Xiao, L. Yang. A Parameter Extraction Method for Five-parameter Model of Photovoltaic Cells, Power System Protection and Control, vol. 41, no.22 pp. 46-50, (2013).

[10] S. Dezsos, T. Remus, R. Pedro, Panel Model Based on Data Sheet Values. Proceedings of 2007 IEEE International Symposium on Industrial Electronics, (2007) June4-7, Vigo, Spain, pp.2392-2396

[11] K. Ishaque, Z. Salam, M. Amjad, S. Mekhilef, An Improved Particle Swarm Optimization (PSO)-based MPPT for PV with Reduced Steady-state Oscillation, IEEE Trans. Power Electron. vol.27, pp. 36273638, (2012).

[12] H. Y. Hu, K. M. Hu, M. Q. Wang. Analytical Study on The Parameters of Single Silicon Solar Cell Model Based on BP Neural Network, Computer Applications and Software, vol. 31, no.3 pp. 55-58, (2014).

[13] G. Walker, Evaluating MPPT Converter Topologies Using a MATLAB PV Model, J. Electr. Electron. 
Eng. Aus, vol. 21, no.1, pp. 49-56, (2001).

[14] W. De. Soto, S. A. Klein, and W. A. Beckman, Improvement and Validation of A Model for Photovoltaic Array Performance, ELSEVIER Solar Energy, vol. 80, pp. 78-88, (2006).

[15] E. Skoplaski, A. G. Boudouvis and J. A. Polyvos, A Simple Correlation for The Operating Temperature of Photovoltaic Modules of Arbitrary Mounting, ELSEVIER Solar Energy Materials, pp.1393-1402, (2008).

[16] M. G. Villalva, J. R. Gazoli, E. R. Filho, Comprehensive Approach to Modeling and Simulation of Photovoltaic Arrays, IEEE Transaction on Power Electronics, vol. 24, issue: 5, pp.1198-1208, (2009).

[17] Solarex data sheets, www.solarex.com

\section{Author}

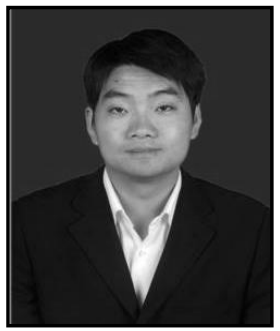

Peng Zhang, He received the Bachelor's degree in power engineering in 2003 from Xi'an University of Technology, China, the Master's degree in electrical engineering in 2011 from Lanzhou Jiaotong University, China. He is currently a lecturer at the school of physics and electrical engineering, Weinan Normal University. His current research interests include computer-aided simulation techniques, distributed generation, and renewable energy. 
International Journal of Grid and Distributed Computing Vol. 9, No. 8 (2016) 